\title{
Article
}

\section{Thermodynamic study of direct amination of isobutylene to tert-butylamine}

\author{
Shangyao Gao a,b, Xiangxue Zhu a,\#, Xiujie Li a, Yuzhong Wang a , Ye Zhang c, Sujuan Xie a, Jie An a, \\ Fucun Chen a, Shenglin Liu a, Longya $\mathrm{Xu}$ a,* \\ a Dalian National Laboratory for Clean Energy, Dalian Institute of Chemical Physics, Chinese Academy of Sciences, Dalian 116023, Liaoning, China \\ b University of Chinese Academy of Sciences, Beijing 100049, China \\ c PetroChina Fushun Petrochemical Company, Fushun 113004, Liaoning, China
}

\section{A R T I C L E I N F O}

\section{Article history:}

Received 26 September 2016

Accepted 23 October 2016

Published 5 January 2017

\section{Keywords:}

Thermodynamic calculation

Isobutylene

Amination

Tert-butylamine

ZSM-11 zeolite

\begin{abstract}
A B S T R A C T
On basis of thermodynamic empirical equations, the thermodynamic parameters for the direct amination of isobutylene to tert-butylamine, an atomically economic and green chemical reaction, were calculated. In particular, the equilibrium conversion of isobutylene under various reaction conditions close to those used in industry was calculated and discussed. Isobutylene amination is a temperature sensitive reaction due to its exothermic nature and isobutylene equilibrium conversion decreases with temperature. However, kinetically, the amination reaction will be faster at a higher temperature. Thus, there must be an optimum temperature for the reaction. A high pressure and $n\left(\mathrm{NH}_{3}\right) / n\left(i-\mathrm{C}_{4} \mathrm{H}_{8}\right)$ molar ratio promote the transformation of isobutylene to tert-butylamine. Developing a highly efficient catalyst under mild reaction conditions is preferred for the amination process. The reaction was investigated over a series of acidic zeolites. ZSM-11 zeolite exhibited the best performance with $14.2 \%$ isobutylene conversion ( $52.2 \%$ of the equilibrium conversion) and > 99.0\% tert-butylamine selectivity. The effect of reaction conditions on the performance of the ZSM-11 catalyst agreed with the thermodynamic results, which provides guidance for further catalyst development and reaction condition optimization.
\end{abstract}

(C) 2016, Dalian Institute of Chemical Physics, Chinese Academy of Sciences. Published by Elsevier B.V. All rights reserved.

\section{Introduction}

Tert-butylamine is an important compound which is widely used as an intermediate in applications including pharmaceuticals, agricultural chemicals, and rubber chemicals [1]. However, so far, the hydrolysis of tert-butylurea, hydrocyanic acid process and other production methods of tert-butylamine encounter many problems, such as using a strong acid and alkali, and massive emission of waste and highly toxic materials [2-4].
In contrast, the direct amination of isobutylene to tert-butylamine is an atomically economic and green chemical process. Deeba and Ford [5] reported that the performance of solid acid catalysts for the amination of isobutylene was related to the number of strong acid sites. However, the reaction was performed under the reaction conditions of $0.15 \mathrm{MPa}, 493 \mathrm{~K}$ and $n\left(\mathrm{NH}_{3}\right) / n\left(i-\mathrm{C}_{4} \mathrm{H}_{8}\right)=2$ [5], which were far from those of industrial use (generally high pressure, as discussed in Section 3.2.5.). BASF first industrialized the isobutylene amination

\footnotetext{
* Corresponding author. Tel/Fax: +86-411-84379279; E-mail: lyxu@dicp.ac.cn

\# Corresponding author. Tel/Fax: +86-411-84379279; E-mail: zhuxx@dicp.ac.cn

This work was supported by K. C. Wong Education Foundation, Youth Innovation Promotion Association of CAS (20120155) and Dalian Eminent Young Scientist Program (2015R009).

DOI: 10.1016/S1872-2067(16)62550-0 | http://www.sciencedirect.com/science/journal/18722067 | Chin. J. Catal., Vol. 38, No. 1, January 2017
} 
process over a $\beta$ zeolite catalyst, but the condition was rather harsh due to the fact that the reaction pressure was as high to $28 \mathrm{MPa}$ [6], which was not conducive to the manufacture of the reactor and related equipment, as well as process energy consumption.

Also, in previous studies, little was discussed about the thermodynamics of the direct amination of isobutylene, especially the equilibrium conversion of isobutylene and its variation under the relative mild reaction conditions available for future industrial use. In the present work, thermodynamic data, namely, $\Delta_{r} H, \Delta_{r} G, K_{p}$, of the direct amination of isobutylene to tert-butylamine were calculated on basis of thermodynamic empirical equations. The equilibrium conversion of isobutylene and its variation with the temperature, pressure and $n\left(\mathrm{NH}_{3}\right) / n\left(i-\mathrm{C}_{4} \mathrm{H}_{8}\right)$ ratio under relative mild reaction conditions (total pressure $<10 \mathrm{MPa}$ ) that would be used in future industrial use were calculated and discussed. The results provide guidance for the optimization of the reaction conditions and for developing a highly active amination catalyst.

The amination was carried out over several zeolite catalysts with different topologies. The results suggested that the catalyst was the key for the process of direct amination of isobutylene to tert-butylamine. The highest conversion of isobutylene, $14.2 \%$ ( $52.2 \%$ of the thermodynamic value), was obtained over a ZSM-11 catalyst. The effect of the reaction conditions on the performance of the ZSM-11 catalyst in an amination system under relatively mild reaction conditions was investigated. The results agreed with the thermodynamic calculation, providing guidance for further catalyst development and the reaction condition optimization of isobutylene amination.

\section{Experimental}

\subsection{Thermodynamic analysis}

The enthalpy change $(\Delta H)$ and Gibbs free energy change $(\Delta G)$ are important in the analysis of chemical reactions. The thermodynamic data were obtained from the relevant thermodynamic manual. The correlation for the enthalpy of formation of the ideal gas is a series expansion in temperature [7].

$$
\Delta_{f} H(T)=A+B \times T+C \times T^{2} \quad(2.1)
$$

$\Delta_{f} H=$ Enthalpy of formation of ideal gas, $\mathrm{kJ} / \mathrm{mol} ; A, B$, and $C=$ Regression coefficient for the chemical compound; $T=$ Temperature, $\mathrm{K}$. The correlation for the Gibbs energy of formation is a series expansion in temperature [7].

$$
\Delta_{f} G(T)=A+B \times T+C \times T^{2}
$$

$\Delta_{f} G=$ Gibbs energy of formation of ideal gas, $\mathrm{kJ} / \mathrm{mol} ; A, B$, and $C$ $=$ Regression coefficient for chemical compound; $T=$ Temperature, $\mathrm{K}$. The equilibrium constant of the reaction is obtained by
Eq. (2.3):

$$
K_{p}=\exp \left[-\left(\Delta_{r} G(T) \times 1000\right) /(R \times T)\right]
$$

$\Delta_{r} G=$ Gibbs free energy of the chemical reaction, $\mathrm{kJ} / \mathrm{mol} ; T=$ Temperature, K; $R=$ Molar gas constant, $8.314 \mathrm{~J} /(\mathrm{mol} \cdot \mathrm{K}) . \Delta_{f} H$, $\Delta_{f} G$ and $K_{p}$ of isobutylene amination to tert-butylamine at different reaction temperatures can be calculated by Eqs. (2.1)-(2.3). The thermodynamic data of the related substances of isobutylene amination are given in Table 1.

\subsection{Catalyst preparation, characterization and testing}

\subsubsection{Catalyst preparation}

All proton-exchanged zeolites of the ZSM-11, MOR, ZSM-5 and SAPO-11 provided by Division of Fossil Energy Conversion of DNL were prepared by three repeated ion exchanges in $\mathrm{NH}_{4} \mathrm{NO}_{3}$ solution $1.0 \mathrm{~mol} / \mathrm{L}$ at $353 \mathrm{~K}$ for $2 \mathrm{~h}$, dried and calcinated at $773 \mathrm{~K}$ for $4 \mathrm{~h}$. The exchange level of the protons in each zeolite was about $100 \%$. Then the zeolite power was crushed to 20-40 mesh for the amination catalytic performance test.

\subsubsection{Catalyst characterization}

Ammonia temperature programmed desorption ( $\mathrm{NH}_{3}$-TPD) was performed in a U-shaped quartz glass microreactor (i.d. = 4 $\mathrm{mm}$ ) with He as the carrier gas. The effluent was monitored by an online gas chromatograph (Shimadzu GC-8A) equipped with a TCD detector. Typically, the sample $(0.14 \mathrm{~g})$ was pretreated at $878 \mathrm{~K}$ for $0.5 \mathrm{~h}$, then cooled down to $423 \mathrm{~K}$ and saturated with $\mathrm{NH}_{3}$. After a stable baseline was obtained, the sample was heated from 423 to $878 \mathrm{~K}$ at a ramp rate of $19.8 \mathrm{~K} / \mathrm{min}$.

Brönsted and Lewis acid sites of the samples were determined by pyridine adsorption followed by infrared (Py-IR) measurement on a VERTEX70 IR spectrometer. The sample was pressed into a self-supporting wafer followed by evacuation at $723 \mathrm{~K}$ for $1 \mathrm{~h}\left(1 \times 10^{-2} \mathrm{~Pa}\right)$ in the IR cell. After the sample was cooled down to $313 \mathrm{~K}$, a spectrum was recorded as the background. Subsequently, the wafer was exposed to pyridine vapor for $5 \mathrm{~min}$ at $313 \mathrm{~K}$ and then outgassed at $423 \mathrm{~K}$ for 30 min. The spectra were collected at $313 \mathrm{~K}$. The amount of Brönsted and Lewis acid sites per gram catalyst were calculated by a method described by Emeis [9].

\subsubsection{Catalyst test}

The direct amination of isobutylene to tert-butylamine was carried out in a stainless steel fixed bed reactor in which the mode of operation was down-flow. The sample was pressed, crushed and sieved into $0.38-0.85 \mathrm{~mm}$ particles before loading into the reactor. $5 \mathrm{~g}$ of catalyst was loaded at the center of the

\begin{tabular}{|c|c|c|c|c|c|c|c|}
\hline \multirow{2}{*}{ Substance } & \multirow{2}{*}{ Molecular Eq. } & \multicolumn{3}{|c|}{$\Delta_{f} H=a+b T+c T^{2}(\mathrm{~kJ} / \mathrm{mol})$} & \multicolumn{3}{|c|}{$\Delta_{f} G=a+b T+c T^{2}(\mathrm{~kJ} / \mathrm{mol})$} \\
\hline & & $a$ & $b$ & $c$ & $a$ & $b$ & $c$ \\
\hline Isobutylene & $\mathrm{C}_{4} \mathrm{H}_{8}$ & $4.13 \mathrm{E}+00$ & $-8.16 \mathrm{E}-02$ & $3.66 \mathrm{E}-05$ & $-1.83 \mathrm{E}+01$ & $2.46 \mathrm{E}-01$ & $3.09 \mathrm{E}-05$ \\
\hline Tert-butylamine & $\mathrm{C}_{4} \mathrm{H}_{11} \mathrm{~N}$ & $-9.08 \mathrm{E}+01$ & $-1.17 \mathrm{E}-01$ & $6.18 \mathrm{E}-05$ & $-1.23 E+02$ & $4.98 \mathrm{E}-01$ & $3.41 \mathrm{E}-05$ \\
\hline Ammonia [8] & $\mathrm{NH}_{3}$ & \multicolumn{3}{|c|}{$\Delta_{f} H=-4 \mathrm{E}-09 T^{3}+2 \mathrm{E}-05 T^{2}-0.034 T-37.515$} & \multicolumn{3}{|c|}{$\Delta_{f} G=6 \mathrm{E}-06 T^{2}+0.1039 T-48.292$} \\
\hline
\end{tabular}

Table 1

Thermodynamic data of related substances of the isobutylene amination reaction [7]. 
reactor and pretreated at $773 \mathrm{~K}$ for $1 \mathrm{~h}$ in $\mathrm{N}_{2}$. The pressure was maintained with $\mathrm{N}_{2}$. After the reactor was cooled down to reaction temperature (493-573 K), liquid ammonia was pumped in to fully fill the reactor before isobutylene was introduced because this feeding sequence favored the reaction [10,11]. The products were analyzed after $2 \mathrm{~h}$ time on-stream by an Agilent 7980B gas chromatograph equipped with a flame ionization detector (FID) and a PONA capillary column.

\section{Results and discussion}

\subsection{Thermodynamic calculation results}

\subsubsection{Changes of $\Delta_{r} H$ of isobutylene amination}

The enthalpy as a function of temperature is an important thermodynamic quantity in thermodynamic modeling [12-14]. The enthalpy of formation for the individual compounds in the chemical reaction is required to determine the heat of reaction, reaction enthalpy $\left(\Delta_{r} H\right)$, and associated heating and cooling requirements [7]. $\Delta_{r} H$ was calculated by Eq. (3.1).

$$
\Delta_{r} H=\sum\left(v \Delta_{f} H\right)_{\text {products }}-\sum\left(v \Delta_{f} H\right)_{\text {reactants }}
$$

$v=$ Chemical reaction coefficient.

Since acidic zeolites afford (90-99)\% selectivity to C2-C4 primary amines (Markovnikov addition) and the selectivity of tert-butylamine was more than $99 \%$ in the present study, tert-butylamine was considered as the only product in isobutylene amination for the thermodynamics data calculation [15-17]. The reaction equation is $i-\mathrm{C}_{4} \mathrm{H}_{8}(\mathrm{IBE})+\mathrm{NH}_{3}=\mathrm{C}_{4} \mathrm{H}_{11} \mathrm{~N}$ (TBA).

The values of $\Delta_{r} H$ in the isobutylene amination reaction at different temperatures are illustrated in Fig. 1. From Fig. 1, we can see that the reaction of isobutylene and ammonia to produce tert-butylamine is a moderately exothermic reaction with the value of $\Delta_{r} H=-56 \mathrm{~kJ} / \mathrm{mol}$ in the investigated temperature range. $\Delta_{r} H$ varied only slightly from -56.3 to $-55.7 \mathrm{~kJ} / \mathrm{mol}$ with the temperature increase from 473 to $573 \mathrm{~K}$. The results suggested that a high temperature is not conducive to the amination reaction from the thermodynamics. The design of a good isobutylene amination catalyst that can work at a low temperature is very important [18]. Also, the $\Delta_{r} H$ value of isobutylene amination indicated that heat removal is needed to maintain a

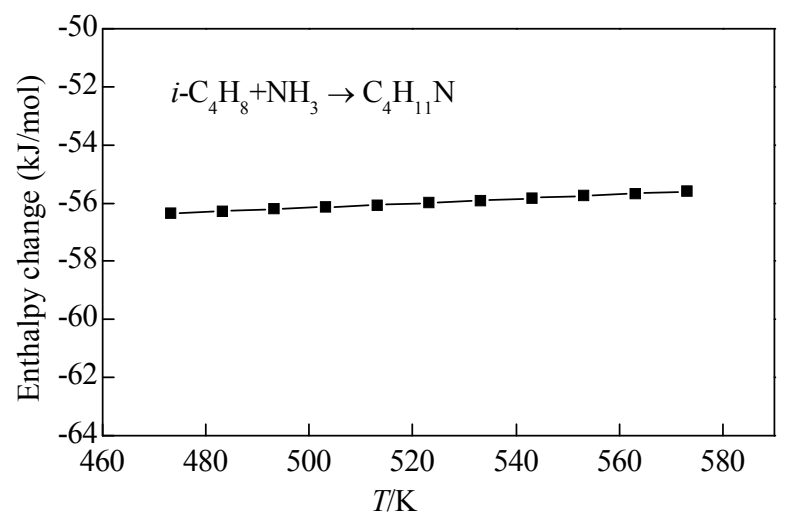

Fig. 1. Enthalpy change of the isobutylene amination reaction at different temperatures. stable reaction temperature when the reaction is carried out in a fixed bed flow reactor because the reaction is highly temperature-sensitive as discussed below.

\subsubsection{Changes of $\Delta_{r} G$ and $K_{p}$ of isobutylene amination}

The Gibbs energy of formation is significant in the analysis of a chemical reaction. The values for the reactants and products are required to determine the change in the Gibbs energy for the reaction. The chemical equilibrium for a reaction is associated with the change in Gibbs free energy $\left(\Delta_{r} G\right)$ for the reaction [7]. $\Delta_{r} G$ was calculated by Eq. (3.2).

$$
\Delta_{r} G=\sum\left(v \Delta_{f} G\right) \text { products }-\sum\left(v \Delta_{f} G\right) \text { reactants }
$$

$v=$ Chemical reaction coefficient.

The changes in the Gibbs energy for a reaction can be used to infer whether the reaction is thermodynamically favorable at given temperature. For quick screening of a chemical reaction, the following rough criteria are useful [6].

$\Delta_{r} G<0 \mathrm{~kJ} / \mathrm{mol}$ (reaction favorable)

$0<\Delta_{r} G<50 \mathrm{~kJ} / \mathrm{mol}$ (reaction possibly favorable)

$\Delta_{r} G>50 \mathrm{~kJ} / \mathrm{mol}$ (reaction not favorable)

The values of $\Delta_{r} G$ of the isobutylene amination reaction at different temperatures are illustrated in Fig. 2. As shown in Fig. $2, \Delta_{r} G$ of isobutylene amination increased linearly with the reaction temperature. When the reaction temperature increased from 473 to $573 \mathrm{~K}$, the value of $\Delta_{r} G$ increased from 13.0 to 27.5 $\mathrm{kJ} / \mathrm{mol}$, indicating that a high temperature is unfavorable for the amination reaction. The reaction cannot be carried out completely with $100 \%$ isobutylene conversion (namely, the reaction can be carried out only to a limited extent) in the above temperature range.

$K_{p}$ of isobutylene amination was calculated by Eq. (2.3). The result is shown in Fig. 3. The value of $K_{p}$ was $<0.04$, which means that isobutylene amination is a reversible process and the forward reaction is thermodynamically unfavorable. Moreover, at a higher temperature, $K_{p}$ is smaller. With the increase of the reaction temperature from 473 to $523 \mathrm{~K}$, the value of $K_{p}$ decreased from $36.7 \times 10^{-3}$ to $9.5 \times 10^{-3}$. The value of $K_{p}$ changed little in the temperature range of 523-573 K. The $K_{p}$ of isobutylene amination is highly sensitive to the temperature, especially in the range of 473 to $523 \mathrm{~K}$, further indicating a low temperature is beneficial for the amination reaction.

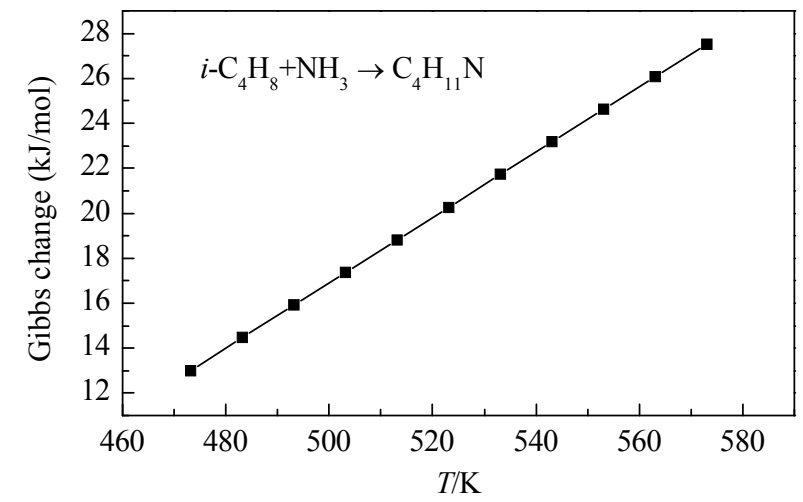

Fig. 2. Gibbs free energy change of isobutylene amination reaction at different temperatures. 


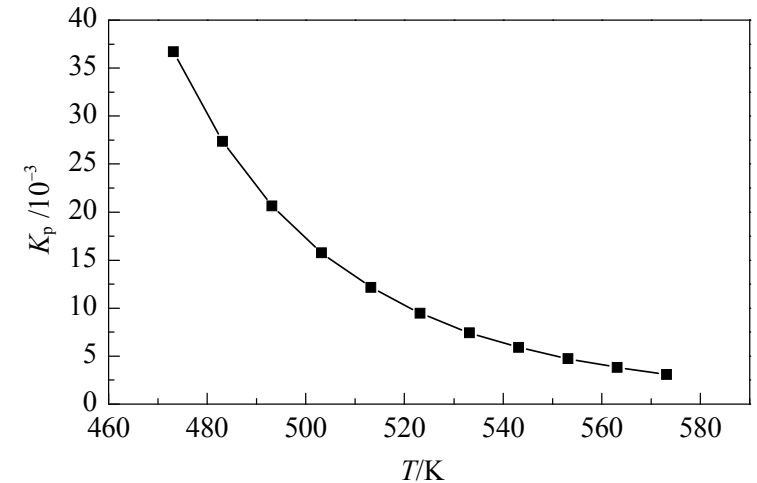

Fig. 3. $K_{p}$ of isobutylene amination reaction at different temperatures.

\subsection{Variation of isobutylene equilibrium conversion with different reaction conditions}

The thermodynamic equilibrium conversion of isobutylene, which is influenced by a set of parameters, including reaction temperature, pressure and $n\left(\mathrm{NH}_{3}\right) / n\left(i-\mathrm{C}_{4} \mathrm{H}_{8}\right)$ ratio, was calculated by the equilibrium constant shown in Eq. (3.4). At a given temperature, the relationship between the equilibrium conversion of isobutylene and parameters, including isobutylene pressure and reactant molar ratio, can be described by Eq. (3.3) and (3.4) [19].

$$
\begin{gathered}
K_{p}=\left(p_{\text {tert-butylamine }} / p^{\circ}\right) /\left[\left(p_{\text {isobutylene }} / p^{\circ}\right) \times\left(p_{\text {ammonia }} / p^{\circ}\right)\right] \\
K_{p}=\left[X_{\text {isobutylene }} \times\left(n+1-X_{\text {isobutylene })]}\right) /\left[\left(1-X_{\text {isobutylene }}\right) \times\right.\right. \\
\left.\left(n-X_{\text {isobutylene }}\right) \times\left(p_{\text {total }} / p^{\circ}\right)\right]
\end{gathered}
$$

$p_{\text {tert-butylamine }}=$ Partial pressure of the tert-butylamine, $\mathrm{Pa} ; p_{\mathrm{i}}$ osbutene $=$ Partial pressure of the isobutylene, $\mathrm{Pa} ; p_{\text {ammonia }}=$ Partial pressure of the ammonia, $\mathrm{Pa} ; p^{\circ}=$ Standard atmospheric pressure, $\mathrm{Pa} ; p_{\text {total }}=$ Total pressure of reaction system; $X_{\text {isobutylene }}$ $=$ Percentage of isobutylene conversion; $n=$ Value of $n\left(\mathrm{NH}_{3}\right) / n\left(i-\mathrm{C}_{4} \mathrm{H}_{8}\right)$ ratio.

\subsubsection{Influence of the reaction temperature}

Fig. 4 gives the influence of temperature on the equilibrium conversion of isobutylene under different pressure in the amination reaction in the temperature range of 473-573 K. We can see that at a higher temperature, the equilibrium conversion is lower. The isobutylene conversion decreased with the reaction temperature under all pressure and $n\left(\mathrm{NH}_{3}\right) / n\left(i-\mathrm{C}_{4} \mathrm{H}_{8}\right)=1$. For example, under $5 \mathrm{MPa}$ and $n\left(\mathrm{NH}_{3}\right) / n\left(i-\mathrm{C}_{4} \mathrm{H}_{8}\right)=1$, the equilibrium conversion of isobutylene dropped from $40.6 \%$ to $6.9 \%$ when the temperature increased from 473 to $573 \mathrm{~K}$, indicating that the reaction is highly temperature sensitive. In other words, from the thermodynamics, the amination of isobutylene to tert-butylamine is favored at a lower reaction temperature due to its exothermic nature, as discussed in Section 3.1.1.

For a chemical reaction, the reaction occurs more rapidly at a higher temperature than at lower temperatures, and the use of a proper higher reaction temperature is indispensable. The rise in temperature leads to both more activated molecules and more effective collisions. As a result, the reaction rate is accelerated with increasing reaction temperature. This is the same

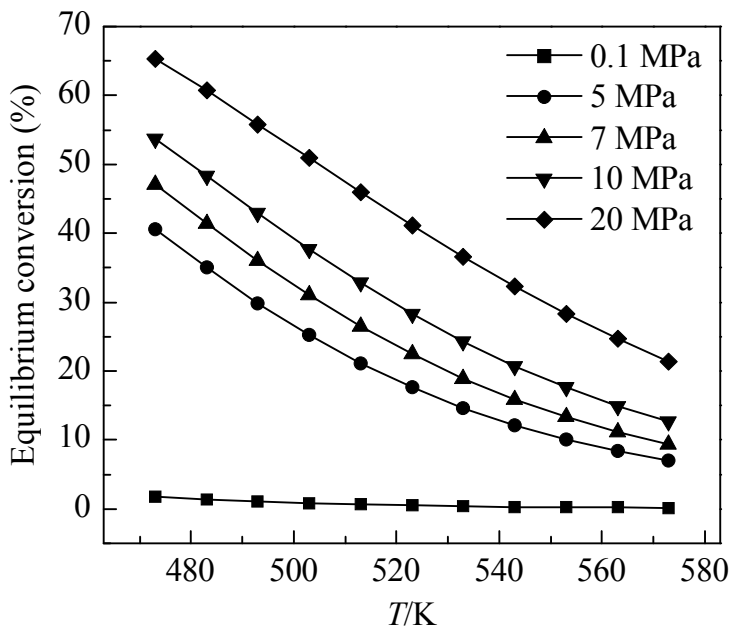

Fig. 4. Influence of temperature on isobutylene equilibrium conversion under different pressures in the amination reaction. $n\left(\mathrm{NH}_{3}\right) / n\left(i-\mathrm{C}_{4} \mathrm{H}_{8}\right)=$ 1.

for the present amination reaction.

The opposing effect of temperature on the thermodynamics and kinetics results in that there must be an optimum temperature for the transformation of isobutylene and ammonia under the given reaction conditions. The above results indicated that a highly active catalyst used at a lower temperature is desired for the isobutylene amination process.

\subsubsection{Influence of reaction pressure}

Fig. 5 gives the influence of pressure on isobutylene equilibrium conversion in the amination reaction in the reaction pressure range of 2-10 MPa under different reaction temperatures and $n\left(\mathrm{NH}_{3}\right) / n\left(i-\mathrm{C}_{4} \mathrm{H}_{8}\right)=1$. From Fig. 5 , we can see that the equilibrium conversion of isobutylene increased with increasing pressure. For example, the equilibrium conversion of isobutylene increased from $8.3 \%$ to $28.3 \%$ with the pressure from 2 to $10 \mathrm{MPa}$ at $523 \mathrm{~K}$ and $n\left(\mathrm{NH}_{3}\right) / n\left(i-\mathrm{C}_{4} \mathrm{H}_{8}\right)=1$.

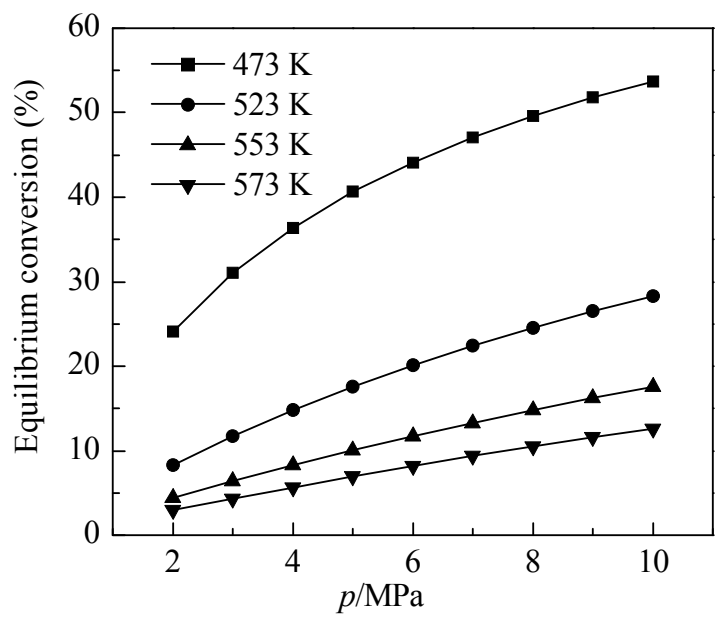

Fig. 5. Influence of pressure on isobutylene equilibrium conversion at different reaction temperatures in the amination reaction. $n\left(\mathrm{NH}_{3}\right) / n\left(i-\mathrm{C}_{4} \mathrm{H}_{8}\right)=1$. 
For a synthesis reaction, like the isobutylene amination reaction, with two reactants producing one compound, increasing the pressure favors moving the chemical equilibrium to the product and increases the equilibrium conversion of the reactants in the thermodynamics. Moreover, for the kinetics, increasing the reaction pressure increase the concentration of the reactant molecules and the contact time of raw materials and catalysts, which promote the transformation of isobutylene and ammonia to tert-butylamine. A high reaction pressure is beneficial for the process of isobutylene amination both from thermodynamics and kinetics. However, too high a pressure is not conducive to the manufacture of the reactor and related equipment, as well as process energy consumption. It is desired to develop a catalyst with high amination activity under a relative low pressure.

\subsubsection{Influence of $n\left(\mathrm{NH}_{3}\right) / n\left(i-\mathrm{C}_{4} \mathrm{H}_{8}\right)$ ratio}

Fig. 6 gives the influence of the $n\left(\mathrm{NH}_{3}\right) / n\left(i-\mathrm{C}_{4} \mathrm{H}_{8}\right)$ ratio on the isobutylene equilibrium conversion under $523 \mathrm{~K}$ and $5 \mathrm{MPa}$ in the amination reaction. It can be seen that the equilibrium conversion of isobutylene increased markedly from $17.6 \%$ to $27.2 \%$ with the increase of $n\left(\mathrm{NH}_{3}\right) / n\left(i-\mathrm{C}_{4} \mathrm{H}_{8}\right)$ from 1 to 4 , and then the conversion increased slowly with further increase in the $n\left(\mathrm{NH}_{3}\right) / n\left(i-\mathrm{C}_{4} \mathrm{H}_{8}\right)$ ratio. For a synthesis reaction of two reactants, increasing the concentration of either of the two reactants will promote the transformation of the other. A relative lower $n\left(\mathrm{NH}_{3}\right) / n\left(i-\mathrm{C}_{4} \mathrm{H}_{8}\right)$ ratio (such as $\left.1-4\right)$ is preferred from the point of view of future industrial use to reduce the operating cost and energy consumption. Here, Section 3.2.4 used the conditions of $5 \mathrm{MPa}, 523 \mathrm{~K}, n\left(\mathrm{NH}_{3}\right) / n\left(i-\mathrm{C}_{4} \mathrm{H}_{8}\right)=4$ and WHSV $=$ $0.5 \mathrm{~h}^{-1}$ to evaluate the amination activity. Under the conditions, the equilibrium conversion of isobutylene in amination is $27.2 \%$.

From the kinetics, besides the use of a rise in temperature, reactant concentration (pressure) and $n\left(\mathrm{NH}_{3}\right) / n\left(i-\mathrm{C}_{4} \mathrm{H}_{8}\right)$ ratio to speed up the transformation of isobutylene to tert-butylamine, a highly efficient catalyst is another choice to accelerate the reaction rate, by which use the activation energy can be lowered and this raises the number and percentage of the activated molecules and promote effective collisions of activated reactant molecules. Developing a high activity catalyst

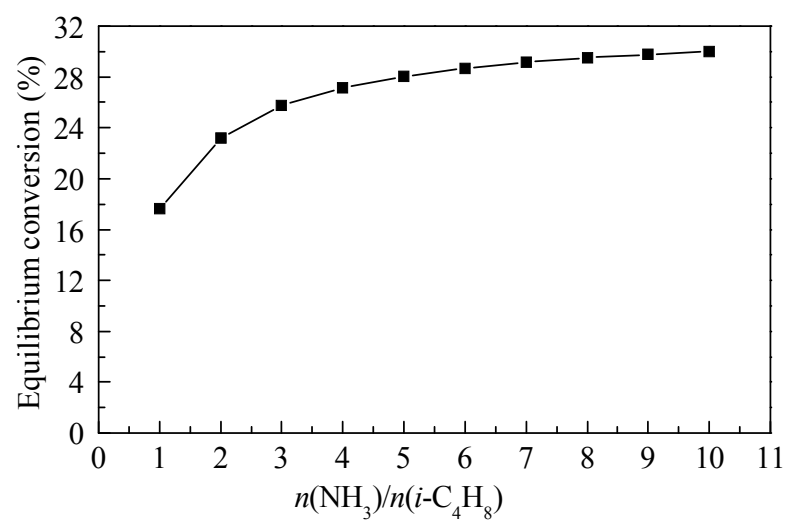

Fig. 6. Influence of $n\left(\mathrm{NH}_{3}\right) / n\left(i-\mathrm{C}_{4} \mathrm{H}_{8}\right)$ ratio on the isobutylene equilibrium conversion. Reaction conditions: $T=523 \mathrm{~K}, p=5 \mathrm{MPa}$. under mild conditions (low temperature and pressure) is the key and is preferred for isobutylene amination.

\subsubsection{Isobutylene amination on several zeolite catalysts with different topologies}

To further show the guidance of the thermodynamics data above and seek an appropriate catalyst, the amination of isobutylene was carried out on several zeolite catalysts with different topologies. The textural and acid properties of the zeolite catalysts are listed in Table 2.

The $\mathrm{NH}_{3}$-TPD profiles for the zeolite catalysts with different topologies are given in Fig. 7. ZSM-11 and ZSM-5 $(R=50)$ showed two desorption peaks at 523 and $723 \mathrm{~K}$, indicating the existence of acid sites with different acid strength [20]. The high temperature (HT) peak of ammonia was attributed to desorption of ammonia bound to strong acid sites. The low temperature (LT) peak corresponded to the desorption of ammonia bound to weak acid sites [21]. It can be seen that ZSM-11 and ZSM-5 $(R=50)$ with a similar $\mathrm{SiO}_{2} / \mathrm{Al}_{2} \mathrm{O}_{3}$ molar ratio exhibited similar acid amount and acid strength. The ZSM-5 $(R=$ 412) catalyst showed just one small HT peak due to its rather low aluminum content [22]. The Brönsted acid concentrations of ZSM-11, ZSM-5 $(R=50)$ and ZSM-5 $(R=412)$ were $0.23,0.16$ and $0.01 \mathrm{mmol} / \mathrm{g}$, respectively, determined by the Py-IR technique at $573 \mathrm{~K}$, as shown in Table 2.

The TPD profiles of MOR also showed two desorption peaks. However, its HT peak centered at $823 \mathrm{~K}$, was higher than those of ZSM-5 $(R=50)$ and ZSM-11. Moreover, the concentrations of the strong acid sites and weak acid sites of MOR were much higher than those of the ZSM-5 $(R=50)$ and ZSM-11, due to its high aluminum content nature, indicated by the $\mathrm{NH}_{3}$-TPD data shown in Fig. 7 and Table 2. This was consistent with result of Ref. [23]. $\mathrm{NH}_{3}$-TPD indicated a large amount of strong acid sites in MOR, whereas a smaller Brönsted acid concentration in MOR was characterized by Py-IR. This may be due to that pyridine was selectively adsorbed on the acidic sites located in the 12-member ring (12-MR) channels of MOR, while the narrow diameter of the 8-MR channels exclude the entrance of pyridine molecules into the 8-MR channels of it [24]. The same situation may partially occur in SAPO- 11 with 10 -MR channels $(0.40 \mathrm{~nm}$ $\times 0.65 \mathrm{~nm}$ ), the size of which are smaller than the kinetic diam-

Table 2

$\mathrm{SiO}_{2} / \mathrm{Al}_{2} \mathrm{O}_{3}$ ratio and acid sites distribution of the zeolite catalysts.

\begin{tabular}{lccccc}
\hline Catalyst & $\begin{array}{c}\mathrm{SiO}_{2} / \mathrm{Al}_{2} \mathrm{O}_{3} \\
\text { ratio }^{a}\end{array}$ & $\begin{array}{c}\text { Total } \\
(\mathrm{mmol} / \mathrm{g})\end{array}$ & $\begin{array}{c}\text { Weak } \\
(\mathrm{mmol} / \mathrm{g})\end{array}$ & $\begin{array}{c}\text { Strong } \\
(\mathrm{mmol} / \mathrm{g})\end{array}$ & $\begin{array}{c}\text { Brönsted } \\
(\mathrm{mmol} / \mathrm{g})\end{array}$ \\
\hline ZSM-11 & 48 & 0.48 & $0.18(523)^{\mathrm{c}}$ & $0.30(723)^{\mathrm{c}}$ & 0.23 \\
ZSM-5 & 50 & 0.53 & $0.20(523)$ & $0.33(723)$ & 0.16 \\
ZSM-5 & 412 & 0.07 & $0.06(493)$ & $0.01(673)$ & 0.01 \\
MOR & 10 & 1.19 & $0.55(523)$ & $0.64(823)$ & 0.16 \\
SAPO-11 & $*$ & 0.22 & $0.18(563)$ & $0.04(723)$ & 0 \\
\hline
\end{tabular}

${ }^{\mathrm{a}} \mathrm{SiO}_{2} / \mathrm{Al}_{2} \mathrm{O}_{3}$ molar ratio was measured by XRF.

b Total acid concentration determined from $\mathrm{NH}_{3}$-TPD.

c Date presented in parentheses was the peak temperature $(\mathrm{K})$ in $\mathrm{NH}_{3}$-TPD.

d Medium and strong acid concentration determined by Py-IR at $573 \mathrm{~K}$.

* Mole composition of SAPO-11, $1.6 \mathrm{Al}_{2} \mathrm{O}_{3}: 1.0 \mathrm{SiO}_{2}: 1.4 \mathrm{P}_{2} \mathrm{O}_{5}$, measured by XRF. 


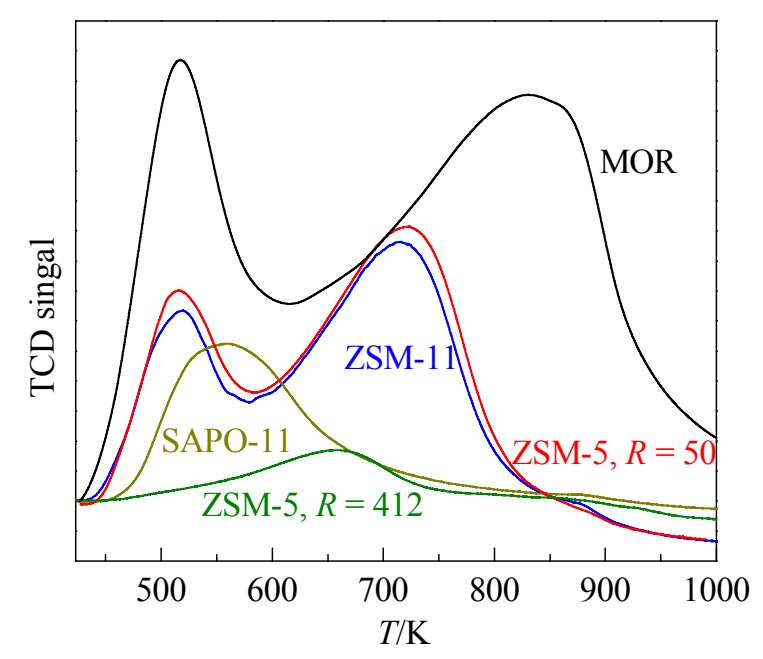

Fig. 7. $\mathrm{NH}_{3}-\mathrm{TPD}$ profiles of the zeolite catalysts with different topologies.

eter of pyridine [25]. On the other hand, as shown in Fig. 7, the acid strength of SAPO-11 was weak and few pyridine molecules were adsorbed on its acidic sites after desorption of pyridine at $573 \mathrm{~K}$.

As discussed in Section 3.1.1, in the isobutylene amination reaction, the selectivity to tert-butylamine was > 99\% (> 99.8\%) under the conditions used. Only very little oligomerization and isomerization products were detected in our study. The catalytic activities of the several zeolite catalysts with different topologies are listed in Table 3. Besides the samples listed in Table 3, the amination reaction of isobutylene was first performed in a blank test under the same reaction conditions used in Table 3. No conversion of isobutylene was observed, which further verified the necessity of developing a highly efficient catalyst for the amination reaction.

Zeolites with a similar pore diameter and $\mathrm{SiO}_{2} / \mathrm{Al}_{2} \mathrm{O}_{3}$ ratio, ZSM-5 $(R=50)$ and ZSM-11 $(R=48)$, exhibited similar amination activity under $5 \mathrm{MPa}, 523 \mathrm{~K}, n\left(\mathrm{NH}_{3}\right) / n\left(i-\mathrm{C}_{4} \mathrm{H}_{8}\right)=4$ and WHSV $=0.5 \mathrm{~h}^{-1}$. The isobutylene conversion over the two samples was $13.9 \%$ and $14.2 \%$, which was $52.2 \%$ of the thermodynamic limit (isobutylene equilibrium conversion). With ZSM-5 ( $R=412)$, with only $0.01 \mathrm{mmol} / \mathrm{g}$ Brönsted acid concentration (strong acid sites), a relatively high isobutylene conversion of $6.4 \%$ was obtained.

On SAPO-11, there was no isobutylene transformation to tert-butylamine, which can be ascribed to its low concentration of mid-strong acid sites and narrow pore diameter, inhibiting the conversion of isobutylene. Besides the samples listed in Table 2 and Table 3 , the reaction was carried out with a $\gamma-\mathrm{Al}_{2} \mathrm{O}_{3}$ sample possessing mainly Lewis acid sites [26]. The amination reaction of isobutylene did not occur and no tert-butylamine was observed.

Interestingly, although MOR zeolite possessed a large amount of acid sites with high acid strength as shown in Fig. 6 and Table 2, the isobutylene conversion on it was only $2.9 \%$, even lower than the value on the high silica ZSM-5 with $\mathrm{SiO}_{2} / \mathrm{Al}_{2} \mathrm{O}_{3}$ ratio of 412 . One reason was that most of the strong
Table 3

Catalytic activities of the catalysts for the amination of isobutylene into tert-butylamine a.

\begin{tabular}{lcc}
\hline Catalyst & Conversion $^{\mathrm{b}}(\%)$ & Selectivity to tert-butylamine ${ }^{\mathrm{c}}(\%)$ \\
\hline ZSM-11 & 14.2 & 99.8 \\
ZSM-5 (50) & 13.9 & 99.8 \\
ZSM-5 (412) & 6.4 & 99.8 \\
MOR & 2.9 & 99.8 \\
\hline a Reaction conditions: $T=523 \mathrm{~K}, p=5 \mathrm{MPa}, n\left(\mathrm{NH}_{3}\right) / n\left(i-\mathrm{C}_{4} \mathrm{H}_{8}\right)=4, \mathrm{WHSV}$ \\
$=0.5 \mathrm{~h}^{-1}$. \\
b Isobutylene reacted (mol)/isobutylene introduced (mol). \\
c Tert-butylamine formed (mol)/total products (mol).
\end{tabular}

acid sites were located in the narrow 8-MR $(0.28 \mathrm{~nm} \times 0.57$ $\mathrm{nm}$ ) channels of the MOR zeolite $[27,28]$, restricting the formation and diffusion of tert-butylamine. The other reason may be that the acid strength of the acid sites in the 12 MR of MOR was excessively strong [29,30]. As indicated by the $\mathrm{NH}_{3}-\mathrm{TPD}$ result, the acid sites with super strong acid strength in the 12 MR of MOR adsorb the alkaline ammonia molecules tightly and prevented the adsorption of isobutylene, suppressing the formation of tert-butylamine. Moreover, the super strong acidity of MOR was not conducive to desorption of the product. All the above resulted in the low conversion of isobutylene on MOR.

The performance of the zeolites with different topologies and alumina in the isobutylene amination reaction suggested that a zeolite with a suitable pore diameter and proper acidity (including acid types, acid strength, and acid concentration) can catalyzed the amination process effectively, further elucidating the importance role of the catalyst in the reaction. Among the catalyst studied, ZSM-11 zeolite exhibited the best performance in the amination process, so it was chosen as the catalyst to study the effect of reaction conditions on the process. Then the results were compared with those of the predictions from thermodynamics and kinetics in Section 3.2.

\subsubsection{Variation of amination performance of ZSM-11 with the} reaction conditions and comparison with the thermodynamics

We investigated the catalytic of performance of ZSM-11 in the amination reaction with temperature, pressure and $n\left(\mathrm{NH}_{3}\right) / n\left(i-\mathrm{C}_{4} \mathrm{H}_{8}\right)$ ratio under the mild reaction conditions expected for future industrial use. The results were compared with those of the prediction from thermodynamics and kinetics. The selectivity to tert-butylamine in the process was $>99.5 \%$ on ZSM-11 under the reaction conditions studied and therefore the performance of the catalyst focused on isobutylene conversion in its amination reaction.

Fig. 8 gives the effect of temperature on isobutylene conversion over ZSM-11 zeolite in isobutylene amination. As can be seen, the isobutylene conversion increased from $5.1 \%$ to $14.2 \%$ as the temperature rose from 493 to $523 \mathrm{~K}$ under $5 \mathrm{MPa}$, $n\left(\mathrm{NH}_{3}\right) / n\left(i-\mathrm{C}_{4} \mathrm{H}_{8}\right)=4$ and WHSV $=0.5 \mathrm{~h}^{-1}$. However, the conversion decreased markedly at the high reaction temperature. At $573 \mathrm{~K}$, the isobutylene conversion was only $7.9 \%$. In the range of 473 to $523 \mathrm{~K}$, a high temperature led to both a larger amount of activated reactant molecules and more effective collisions between the activated isobutylene and ammonia 


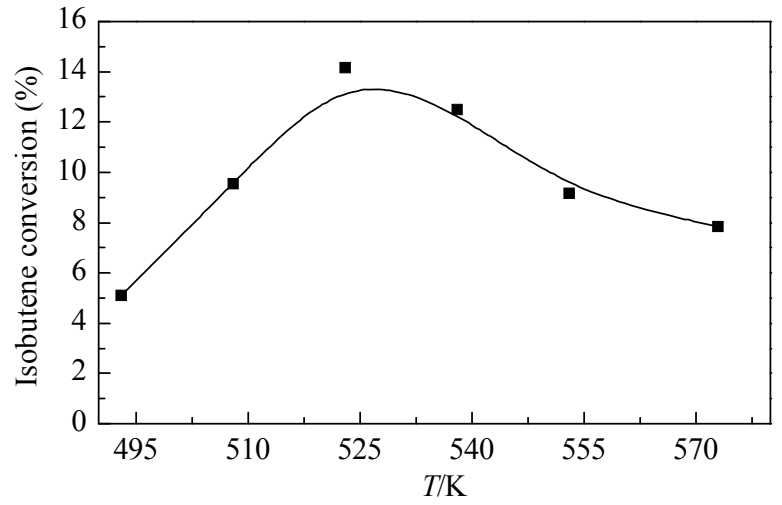

Fig. 8. Effect of temperature on isobutylene conversion of the amination reaction over ZSM-11. Reaction conditions: $p=5 \mathrm{MPa}$, $n\left(\mathrm{NH}_{3}\right) / n\left(i-\mathrm{C}_{4} \mathrm{H}_{8}\right)=4$, WHSV $=0.5 \mathrm{~h}^{-1}$.

molecules, which enhanced the isobutylene amination to tert-butylamine. However, due to the exothermic and highly temperature-sensitive nature of the amination reaction, as illustrated in Fig. 4, the further rise in temperature above $523 \mathrm{~K}$ made the reaction thermodynamically unfavorable, in agreement with the thermodynamics and dynamics results in Section 3.2.1.

Fig. 9 shows the effect of reaction pressure on isobutylene conversion over ZSM-11 zeolite in isobutylene amination under $523 \mathrm{~K}, n\left(\mathrm{NH}_{3}\right) / n\left(i-\mathrm{C}_{4} \mathrm{H}_{8}\right)=4$ and WHSV $=0.5 \mathrm{~h}^{-1}$ of isobutylene. As can be seen, the isobutylene conversion increased almost linearly with the increase of reaction pressure under the investigated conditions. Under the pressure of 3.0 and 7.0 MPa, the value of isobutylene conversions was $10.1 \%$ and $16.3 \%$, respectively. The following parameters, namely, the concentrations of isobutylene and ammonia in the reaction system, effective collisions of activated isobutylene and ammonia molecules, as well as the contact time of the reactants with the ZSM-11 catalyst all increased with the reaction pressure, accelerating the reaction rate of isobutylene amination. Moreover, the equilibrium conversion of isobutylene in amination was also increased with the increase of reaction pressure as illustrated in Section 3.2.2. The above results further verified that a high reaction pressure was beneficial to the process of isobutylene

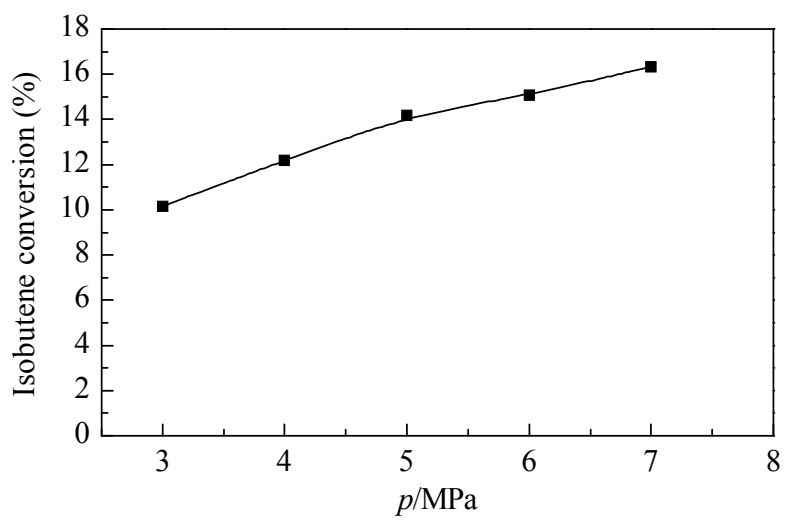

Fig. 9. Effect of pressure on isobutylene conversion of amination over ZSM-11. Reaction conditions: $T=523 \mathrm{~K}, n\left(\mathrm{NH}_{3}\right) / n\left(i-\mathrm{C}_{4} \mathrm{H}_{8}\right)=4$, WHSV $=$ $0.5 \mathrm{~h}^{-1}$. amination, both by thermodynamics and kinetics.

The isobutylene amination reaction under different $n\left(\mathrm{NH}_{3}\right) / n\left(i-\mathrm{C}_{4} \mathrm{H}_{8}\right)$ molar ratios (i.e. $\left.1.5,2,3,4,5,6,8\right)$ was conducted to learn its effect on the catalytic performance of the ZSM-11 catalyst. As shown in Fig. 10, isobutylene conversion increased from $11.4 \%$ to $14.8 \%$ when the $n\left(\mathrm{NH}_{3}\right) / n\left(i-\mathrm{C}_{4} \mathrm{H}_{8}\right)$ ratio increased from 1.5 to 5 at $523 \mathrm{~K}, 5 \mathrm{MPa}$, WHSV $=0.5 \mathrm{~h}^{-1}$ of isobutylene. With further raising of the $n\left(\mathrm{NH}_{3}\right) / n\left(i-\mathrm{C}_{4} \mathrm{H}_{8}\right)$ ratio, the conversion of isobutylene decreased gradually. For example, when the $n\left(\mathrm{NH}_{3}\right) / n\left(i-\mathrm{C}_{4} \mathrm{H}_{8}\right)=8$, isobutylene conversion even dropped to $12.3 \%$.

According to Le Chatelier's principle, as discussed in Section 3.2.3, increasing the concentration of ammonia would promote the transformation of isobutylene. When the $n\left(\mathrm{NH}_{3}\right) / n\left(i-\mathrm{C}_{4} \mathrm{H}_{8}\right)$ ratio was lower than 5 , the rise of the $n\left(\mathrm{NH}_{3}\right) / n\left(i-\mathrm{C}_{4} \mathrm{H}_{8}\right)$ ratio (rise in the concentration of ammonia) in the reactants would enhance the transformation of isobutylene to tert-butylamine. However, under the above conditions, too high a $n\left(\mathrm{NH}_{3}\right) / n\left(i-\mathrm{C}_{4} \mathrm{H}_{8}\right)$ ratio meant reducing the partial pressure (concentration) of isobutylene and the contact time between the reactants and the catalyst, resulting in the drop of isobutylene conversion with further increasing the value of $n\left(\mathrm{NH}_{3}\right) / n\left(i-\mathrm{C}_{4} \mathrm{H}_{8}\right)$ ratio above 5 .

The influence of the WHSV of isobutylene on the performance of ZSM-11 is shown in Fig. 11. Under the conditions of $523 \mathrm{~K}, 5 \mathrm{MPa}, n\left(\mathrm{NH}_{3}\right) / n\left(i-\mathrm{C}_{4} \mathrm{H}_{8}\right)=4$, the selectivity to tert-butylamine slightly decreased but was still $>99 \%$ with the WHSV reduction from 1.2 to $0.3 \mathrm{~h}^{-1}$. At the same time, the conversion of isobutylene increased from $11.0 \%$ to $14.9 \%$ due to the prolonged contact time of the reactant molecules with the catalyst.

According to above results, the mild conditions of $523 \mathrm{~K}$, 5-7 MPa, $n\left(\mathrm{NH}_{3}\right) / n\left(i-\mathrm{C}_{4} \mathrm{H}_{8}\right)$ ratio of 3-5 and WHSV of isobutylene $0.3-0.8 \mathrm{~h}^{-1}$ were preferred to enhance the high efficiency and atomically economic transformation of isobutylene to tert-butylamine on a ZSM-11 zeolite catalyst.

\section{Conclusions}

The direct amination of isobutylene to tert-butylamine is an atomically economic and green chemical process. Based on

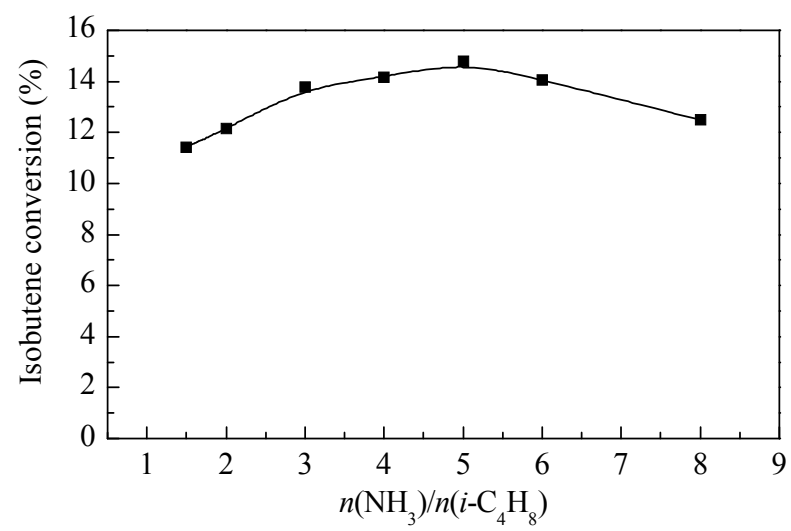

Fig. 10. Effect of $n\left(\mathrm{NH}_{3}\right) / n\left(i-\mathrm{C}_{4} \mathrm{H}_{8}\right)$ ratio on isobutylene conversion over ZSM-11. Reaction conditions: $T=523 \mathrm{~K}, p=5 \mathrm{MPa}$, WHSV $=0.5 \mathrm{~h}^{-1}$. 


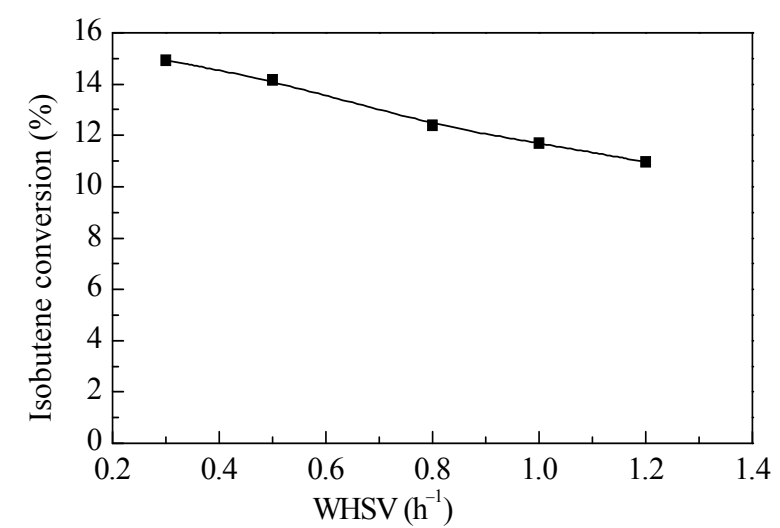

Fig. 11. Effect of WHSV of isobutylene on isobutylene conversion over ZSM-11. Reaction conditions: $T=523 \mathrm{~K}, p=5 \mathrm{MPa}, n\left(\mathrm{NH}_{3}\right) / n\left(i-\mathrm{C}_{4} \mathrm{H}_{8}\right)=$ 4.

thermodynamic empirical equations, thermodynamic data, esp. the equilibrium conversion of isobutylene and its variation with the reaction conditions, were calculated and discussed. The reaction is moderately exothermic and thermodynamically unfavorable, which was verified by that the isobutylene equilibrium conversion decreased with temperature. The increase of reaction pressure and $n\left(\mathrm{NH}_{3}\right) / n\left(i-\mathrm{C}_{4} \mathrm{H}_{8}\right)$ ratio was beneficial to the amination reaction due to the thermodynamics. To enhance the transformation of isobutylene to tert-butylamine, developing a highly efficient catalyst that can perform under mild reaction conditions is desired for future industrial application. A zeolite with a suitable pore diameter and proper acidity can catalyzed the amination process effectively under mild conditions. Among the tested samples, ZSM-11 exhibited the best performance with $14.2 \%$ isobutylene conversion $(52.2 \%$ of the equilibrium conversion) and $>99.0 \%$ tert-butylamine selectivity. The effect of the reaction conditions on the performance of ZSM-11 catalyst in an amination system agreed with the thermodynamic results. There is a maximum isobutylene conversion at a moderate reaction temperature, and a high pressure with appropriate high $n\left(\mathrm{NH}_{3}\right) / n\left(i-\mathrm{C}_{4} \mathrm{H}_{8}\right)$ ratio. The results provide guidance for further catalyst design and reac- tion condition optimization in the isobutylene amination process.

\section{References}

[1] J. C. Zhou, X. S. Wang, Chem. Ind. Eng. Progr., 1998, (4), 20-23.

[2] V. E. Antipanova, V. T. Gilmkhanova, L. V. Voronkova, I. B Proshkin, Khimst (Moscow), 1988, 12, 720-722.

[3] M. V. Twigg, EP 0211 552, 1987.

[4] H. S. Fales, J. O. H. Peterson, EP 0039 918, 1981.

[5] M. Deeba, M. E. Ford, J. Org. Chem., 1988, 53, 4594-4596.

[6] U. Dingerdissen, R. Kummer, P. Stops, U. Müller, J. Herrmann, K. D. Eller, US Patent 6143 934, 2000.

[7] C. L. Yaws, Chemical Properties Handbook, 1st ed., McGraw-Hill, New York, 1999, 288-339.

[8] M. L. Williams, Handbook of Chemistry and Physics, 76th ed., CRC Press, Boca Raton, 1995, 61-84.

[9] C. A. Emeis, J. Catal., 1993, 141, 347-354.

[10] Y. F. Ma, X. M. Jin, S. Z. Guo, X. T. Shu, Y. Shu, Petrochem Technol, 2006, 35, 720-724.

[11] M. Bergfeld, M. Nywlt, US Patent 5648 546, 1997.

[12] W. Huang, Y. A. Chang, Intermetallics, 1998, 6, 487-498.

[13] W. Huang, Y. A. Chang, Intermetallics, 1999, 7, 863-874.

[14] I. Ansara, N. Dupin, H. L. Lukas, B. Sundman, J. Alloys Compd., 1997, $247,20-30$.

[15] J. O. H. Peterson, H. S. Fales, US Patent 4375 002, 1983.

[16] W. F. Hölderich, H. van Bekkum, Stud. Surf. Sci. Catal., 1991, 58, 631-726.

[17] D. W. Blackburn, Catalysis of Organic Reaction, 12th ed., Marcel Dekker Inc., New York, 1989, 40, 241-242.

[18] O. Jimenez, T. E. Müller, C. Sievers, A. Spirkl, J. A. Lercher, Chem Commun., 2006, 2974-2976.

[19] X. C. Fu, W. X. Shen, T. Y. Yao, W. H. Hou, Physical Chemistry, 5th ed., Higher Education Press, Beijing, 2005, 352-355.

[20] N. Katada, H. Igi, J. H. Kim, M. Niwa, J. Phys. Chem. B, 1997, 101, 5969-5977.

[21] G. Öhlmann, H. Pfeifer, R. Fricke, Catalysis and Adsorption by Zeolites, Elsevier, Amsterdam, 1991, 133-156.

[22] M. H. W. Sonnemans, C. D. Heijer, M. Crocker, J. Phys. Chem., 1993, 97, 440-445.

[23] S. M. K. Aboul-Fotouh, N. A. K. Aboul-Gheit, M. M. I. Hassan, Chin. J. Catal., 2011, 32, 412-417.

\section{Graphical Abstract}

Chin. J. Catal., 2017, 38: 106-114 doi: 10.1016/S1872-2067(16)62550-0

\section{Thermodynamic study of direct amination of isobutylene to tert-butylamine}

Shangyao Gao, Xiangxue Zhu*, Xiujie Li, Yuzhong Wang, Ye Zhang, Sujuan Xie, Jie An, Fucun Chen, Shenglin Liu, Longya Xu*

Dalian Institute of Chemical Physics, Chinese Academy of Sciences

Thermodynamic calculation of the direct amination of isobutylene to tert-butylamine, an atomically economic and green chemical process, provide guidance for developing a highly efficient catalyst and reaction condition optimization.

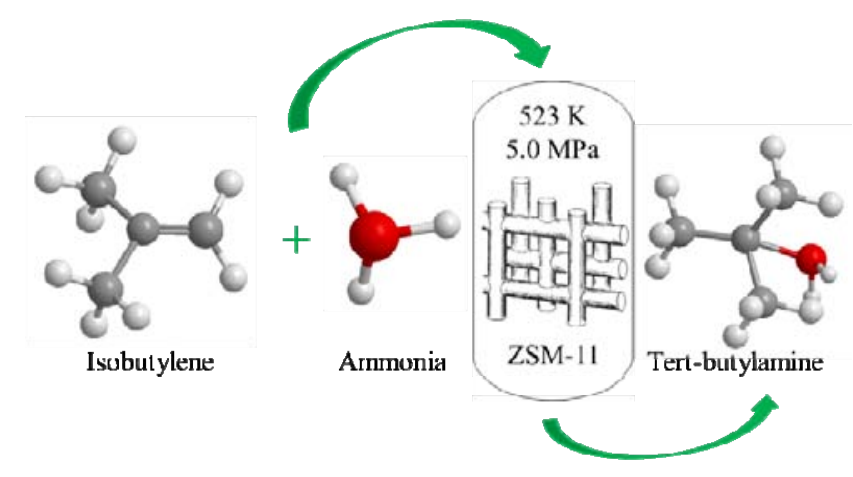


[24] J. L. Liu, H. F. Xue, X. M. Huang, P. H. Wu, S. J. Huang, S. B. Liu, W. J. Shen, Chin. J. Catal., 2010, 31, 729-738.

[25] B. Li, P. Tian, Y. Qi, L. Zhang, S. T. Xu, X. Su, D. Fan, Z. M. Liu, Chin. J. Catal., 2013, 34, 593-603.

[26] M. Nagai, K. Koizumi, S. Omi, Catal. Today, 1997, 35, 393-405.

[27] T. Sano, S. Wakabayashi, Y. Oumi, T. Uozumi, Microporous Mesoporous Mater., 2001, 46, 67-74.
[28] A. Bhan, A. D. Allian, G. J. Sunley, D. J. Law, E. Iglesia, J. Am. Chem. Soc., 2007, 129, 4919-4924.

[29] M. Kato, K. Itabashi, A. Matsumoto, K. Tsutsumi, J. Phys. Chem. B, 2003, 107, 1788-1797.

[30] P. Bodart, J. B. Nagy, G. Debras, Z. Gabelica, P. A. Jacobs, J. Phys. Chem., 1986, 90, 5183-5190.

\section{异丁烯直接胺化合成叔丁胺反应的热力学研究}

高尚耀 ${ }^{\mathrm{a}, \mathrm{b}}$, 朱向学 $\mathrm{a}$, , , 李秀杰 ${ }^{\mathrm{a}}$, 王玉忠, 张 烨, 谢素娟 ${ }^{\mathrm{a}}$, 安 杰 ${ }^{\mathrm{a}}$, 陈福存 ${ }^{\mathrm{a}}$, 刘盛林 ${ }^{\mathrm{a}}$, 徐龙伢, ${ }^{\mathrm{a}}$

a 中国科学院大连化学物理研究所洁净能源国家实验室(筹), 辽宁大连 116023

b 中国科学院大学, 北京100049

${ }^{\mathfrak{c}}$ 中国石油天然气股份有限公司抚顺石化分公司石油二厂, 辽宁抚顺 113008

摘要: 叔丁胺是一种重要的有机化工中间体, 广泛应用于制备橡胶促进剂, 医药, 农药, 着色剂等诸多下游产物. 目前, 叔丁 胺主要的生产方法, 如叔丁嫝水解法, 异丁烯-氢氰酸法 (Ritter 法), 卤代烃胺化法等存在产品收率较低, 涉及强酸/强碱的使 用, 对设备腐蚀和环境污染严重等问题. 异丁烯直接胺化生产叔丁胺, 原子利用率 $100 \%$, 是典型的绿色化学反应.

20 世纪末, BASF 公司以 $\beta$ 沸石为催化剂, 率先实现了异丁烯胺化技术的工业应用. 但是, 其反应条件苛刻, 压力达 28 $\mathrm{MPa}$, 生产过程能耗大, 对设备材质要求高. 目前, 关于异丁烯直接胺化的文献较少, 且相关研究多在远离工业应用的常压 条件下进行. 同时, 对于异丁烯直接胺化反应过程的热力学, 特别是缓和反应条件下的热力学尚待进一步系统和深入地研 究分析, 以期指导低温低压条件下高性能胺化催化剂的研发和工艺条件优化.

我们计算了 473-573 K 间, 异丁烯胺化制备叔丁胺反应的 $\Delta_{r} H, \Delta_{r} G, K_{p}$ 等热力学数据. 在此基础上, 分析了反应温度, 压力和氨烯比 (摩尔比) 对异丁烯平衡转化率 (叔丁胺选择性 $>99 \%$, 未予考虑) 的影响. 结果表明, 异丁烯胺化是中等强度 的放热反应, 升高反应温度会急剧降低异丁烯的平衡转化率, 如在 $5 \mathrm{MPa}$, 氨烯比 1 的条件下, 反应温度从 $473 \mathrm{~K}$ 提高到 $573 \mathrm{~K}$, 异丁烯平衡转化率从 $40.6 \%$ 降到 $6.9 \%$. 但从动力学角度而言, 升温可提高胺化反应速率, 因此在特定的反应条件下 和催化剂上, 必然存在最佳反应温度. 提高反应压力和氨烯比有利于提高异丁烯的热力学平衡转化率. 开发在低温和相对 较低的压力下具有较高胺化活性的催化剂是提高该过程经济性和实用性的关键.

在较缓和的反应条件下 $\left(523 \mathrm{~K}, 5 \mathrm{MPa}\right.$, 氨烯比 4 及异丁烯空速 $\left.0.5 \mathrm{~h}^{-1}\right)$, 考察了 ZSM-5 $(R=50$ 和 $R=412, R$ 为硅铝比, 下 同), ZSM-11( $R=48), \mathrm{MOR}(R=10), \mathrm{SAPO}-11$ (摩尔组成, $1.6 \mathrm{Al}_{2} \mathrm{O}_{3}: 1.0 \mathrm{SiO}_{2}: 1.4 \mathrm{P}_{2} \mathrm{O}_{5}$ ) 等不同拓扑结构分子篮以及氧化铝在异丁 烯胺化反应中的性能. 结果表明, 空白试验中, 无叔丁胺产物生成. 在 ZSM-11 上的获得最高的异丁烯胺化转化率, 为 $14.2 \%$ (达到平衡转化率的 $52.2 \%$ ), 在 ZSM-5 $(R=50), Z S M-5(R=412)$ 和 MOR 上, 异丁烯转化率分别为 $13.9 \%, 6.4 \%$ 和 $2.9 \%$, 叔丁胺选择性均大于 $99.8 \%$. 而 SAPO-11 和氧化铝未呈现出胺化反应活性. 关联氨气程序升温脱附, 吡啶吸附红外 表征结果及分子篮孔结构特点, 表明分子篮胺化活性与其孔径及 Brönsted 酸的酸量和酸强度密切相关.

为了进一步验证实际反应体系中反应条件对异丁烯胺化反应过程的影响规律, 我们在 ZSM-11 催化剂上, 系统考察了 反应温度, 压力, 氨烯比和异丁烯空速对催化剂胺化反应性能的影响及变化规律. 结果表明, 在其他条件不变的情况下, 异 丁烯转化率随着温度的升高呈现出先增大后减小的趋势. 适当提高原料中氨烯比和反应压力, 以及采用较低异丁烯空速 有利于促进异丁烯的转化. 上述规律与热力学计算结果呈现出较好的一致性. 在 ZSM-11 催化剂上, 异丁烯直接胺化反应 的较佳反应条件为 $523 \mathrm{~K}, 5 \mathrm{MPa}$, 氨烯比 4 , 异丁烯空速 $0.5 \mathrm{~h}^{-1}$. 上述结果可为异丁烯直接胺化合成叔丁胺过程新型高效 催化剂的研发和反应工艺条件优化提供参考和指导.

关键词: 热力学计算; 异丁烯; 胺化; 叔丁胺; ZSM-11 分子篮

收稿日期: 2016-09-26. 接受日期: 2016-10-23. 出版日期: 2017-01-05.

*通讯联系人. 电话/传真: (0411)84379279; 电子信箱: 1yxu@dicp.ac.cn

通讯联系人. 电话/传真: (0411)84379279; 电子信箱: zhuxx@dicp.ac.cn

基金来源: 王宽诚教育基金会; 中科院青年创新促进会 (20120155); 大连市高层次人才创新支持计划 (2015R009).

本文的英文电子版由Elsevier出版社在ScienceDirect上出版(http://www.sciencedirect.com/science/journal/18722067). 